\title{
Mature results of a phase II trial on individualised accelerated radiotherapy based on normal tissue constraints in concurrent chemo-radiation for stage III non-small cell lung cancer
}

Citation for published version (APA):

van Baardwijk, A., Reymen, B., Wanders, S., Borger, J., Ollers, M., Dingemans, A-M. C., Bootsma, G., Geraedts, W., Pitz, C., Lunde, R., Peters, F., Lambin, P., \& De Ruysscher, D. (2012). Mature results of a phase II trial on individualised accelerated radiotherapy based on normal tissue constraints in concurrent chemo-radiation for stage III non-small cell lung cancer. European Journal of Cancer, 48(15), 2339-2346. https://doi.org/10.1016/j.ejca.2012.04.014

Document status and date:

Published: 01/10/2012

DOI:

10.1016/j.ejca.2012.04.014

Document Version:

Publisher's PDF, also known as Version of record

Document license:

Taverne

Please check the document version of this publication:

- A submitted manuscript is the version of the article upon submission and before peer-review. There can be important differences between the submitted version and the official published version of record. People interested in the research are advised to contact the author for the final version of the publication, or visit the DOI to the publisher's website.

- The final author version and the galley proof are versions of the publication after peer review.

- The final published version features the final layout of the paper including the volume, issue and page numbers.

Link to publication

\footnotetext{
General rights rights.

- You may freely distribute the URL identifying the publication in the public portal. please follow below link for the End User Agreement:

www.umlib.nl/taverne-license

Take down policy

If you believe that this document breaches copyright please contact us at:

repository@maastrichtuniversity.nl

providing details and we will investigate your claim.
}

Copyright and moral rights for the publications made accessible in the public portal are retained by the authors and/or other copyright owners and it is a condition of accessing publications that users recognise and abide by the legal requirements associated with these

- Users may download and print one copy of any publication from the public portal for the purpose of private study or research.

- You may not further distribute the material or use it for any profit-making activity or commercial gain

If the publication is distributed under the terms of Article 25fa of the Dutch Copyright Act, indicated by the "Taverne" license above,

Download date: 26 Apr. 2023 


\title{
Mature results of a phase II trial on individualised accelerated radiotherapy based on normal tissue constraints in concurrent chemo-radiation for stage III non-small cell lung cancer ${ }^{\text {th }}$
}

\author{
Angela van Baardwijk ${ }^{\mathrm{a}, *}$, Bart Reymen ${ }^{\mathrm{a}}$, Stofferinus Wanders ${ }^{\mathrm{a}}$, Jacques Borger ${ }^{\mathrm{a}}$, \\ Michel Öllers ${ }^{a}$, Anne-Marie C. Dingemans ${ }^{b}$, Gerben Bootsma ${ }^{c}$, Wiel Geraedts ${ }^{\mathrm{d}}$, \\ Cordula Pitz ${ }^{\mathrm{e}}$, Ragnar Lunde ${ }^{\mathrm{f}, \mathrm{h}}$, Frank Peters ${ }^{\mathrm{g}}$, Philippe Lambin ${ }^{\mathrm{a}}$, Dirk De Ruysscher ${ }^{\mathrm{a}}$
}

\footnotetext{
a Department of Radiation Oncology (MAASTRO Clinic), GROW-School for Oncology and Developmental Biology, Maastricht University Medical Centre, Maastricht, The Netherlands

${ }^{\mathrm{b}}$ Department of Pulmonology, GROW - School for Oncology and Developmental Biology, Maastricht University Medical Centre, Maastricht, The Netherlands

${ }^{\mathrm{c}}$ Department of Pulmonology, Atrium Medical Centre, Heerlen, The Netherlands

${ }^{\mathrm{d}}$ Department of Pulmonology, Orbis Medical Centre, Sittard, The Netherlands

e Department of Pulmonology, Laurentius Hospital, Roermond, The Netherlands

${ }^{\mathrm{f}}$ Department of Pulmonology, Sint Jans Gasthuis, Weert, The Netherlands

${ }^{\mathrm{g}}$ Department of Medical Oncology, Orbis Medical Centre, Sittard, The Netherlands
}

Available online 18 May 2012

\section{KEYWORDS}

Non-small cell lung cancer

Concurrent chemo-radiation

Normal tissue constraints Individualised Combined modality

\begin{abstract}
Background: Sequential chemotherapy and individualised accelerated radiotherapy (INDAR) has been shown to be effective in non-small cell lung cancer (NSCLC), allowing delivering of high biological doses. We therefore performed a phase II trial (clinicaltrials.gov; NCT00572325) investigating the same strategy in concurrent chemo-radiation in stage III NSCLC.

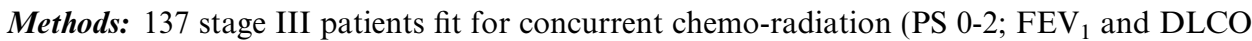
$\geqslant 30 \%$ ) were included from April 2006 till December 2009. An individualised prescribed dose based on normal tissue dose constraints was applied: mean lung dose (MLD) 19 Gy, spinal cord $54 \mathrm{~Gy}$, brachial plexus $66 \mathrm{~Gy}$, central structures $74 \mathrm{~Gy}$. A total dose between 51 and 69 Gy was delivered in 1.5 Gy BID up to 45 Gy, followed by 2 Gy QD. Radiotherapy was started at the 2 nd or 3 rd course of chemotherapy. Primary end-point was overall survival
\end{abstract}

\footnotetext{
Presented in part at the Annual Meeting of ASTRO 2010, San Diego and the Annual Meeting of the World Conference on Lung Cancer 2011, Amsterdam. This article is the first complete report of the study.

* Corresponding author: Tel.: +31 884455 666; fax: +31 884455667.

E-mail address: angela.vanbaardwijk@maastro.nl (A.van Baardwijk).

${ }^{\mathrm{h}}$ Currently working in Laurentius Hospital, Roermond, The Netherlands.
} 
(OS) and secondary end-point toxicity common terminology criteria for adverse events v3.0 (CTCAEv3.0).

Findings: The median tumour volume was $76.4 \pm 94.1 \mathrm{cc} ; 49.6 \%$ of patients had N2 and $32.1 \%$ $\mathrm{N} 3$ disease. The median dose was $65.0 \pm 6.0$ Gy delivered in $35 \pm 5.7$ days. Six patients $(4.4 \%)$ did not complete radiotherapy. With a median follow-up of 30.9 months, the median OS was 25.0 months (2-year OS 52.4\%). Severe acute toxicity ( $\geqslant G 3,35.8 \%$ ) consisted mainly of G3 dysphagia during radiotherapy $(25.5 \%)$. Severe late toxicity $(\geqslant G 3)$ was observed in 10 patients $(7.3 \%)$.

Interpretation: INDAR in concurrent chemo-radiation based on normal tissue constraints is feasible, even in patients with large tumour volumes and multi-level N2-3 disease, with acceptable severe late toxicity and promising 2-year survival.

(c) 2012 Elsevier Ltd. All rights reserved.

\section{Introduction}

Non-small cell lung cancer (NSCLC) is one of the most frequently diagnosed cancers and the leading cause of cancer death. ${ }^{1}$ Stage III disease represents about one third of all NSCLC with concurrent chemo-radiation as treatment of choice ${ }^{2}$ and only for a selected group chemotherapy and surgery. As local tumour control remains low, strategies for improvement have been investigated including increasing radiation dose, accelerated hyperfractionated radiation and targeted agents. ${ }^{3-8}$ Increasing the dose is challenging due to the tolerance of normal tissues, e.g. lung and spinal cord. In most doseescalation trials, a certain threshold for organs at risk has been implemented together with a fixed dose (e.g. 74 Gy). As a consequence, the dose will be dependent on tumour volume; only patients with relatively small volume disease being capable to receive a high dose. In order to deliver the highest possible radiation dose to every individual patient we developed a strategy in which the radiation fields were kept as small as possible with selective nodal irradiation based on Fluordeoxyglucose - Positron Emission Tomography - Computer Tomography (FDG-PET-CT) scans $^{9}$ and accelerated radiotherapy in order to increase the biological effectiveness. ${ }^{10,11}$ As such, patients receive the highest possible biological radiation dose with the best therapeutic ratio. We previously demonstrated that individualised accelerated radiotherapy (INDAR) with radiotherapy alone or sequential chemo-radiation is feasible with acceptable toxicity and promising results. ${ }^{12}$

Another strategy to improve local control and overall survival (OS) is concurrent chemo-radiation., ${ }^{2,5}$ A metaanalysis based study showed a significant benefit in OS for concurrent chemo-radiation compared to sequential chemo-radiation, but at the expense of more transient oesophageal toxicity. ${ }^{2}$ Most patients received a dose of $60 \mathrm{~Gy}$ in 30 fractions in 6 weeks in this meta-analysis, at present considered to be the standard scheme in concurrent chemo-radiation. However, dose escalation in concurrent chemo-radiation seems feasible, ${ }^{3,13}$ and indirect evidence suggests that radiation dose escalation may also improve survival in the context of concurrent chemo-radiation. ${ }^{14}$

We hypothesised that combining concurrent chemoradiation with INDAR based on normal tissue constraints could further improve survival in stage III NSCLC. Here, we report the mature results of a large prospective phase II study applying this INDAR approach in concurrent chemo-radiation.

\section{Methods}

\subsection{Patients}

From 1st April 2006 until 31st December 2009 patients eligible for concurrent chemo-radiation were entered in this prospective study conducted at MAASTRO clinic. Included were patients with stage III, except pleural effusion (Union for International Cancer Control, TNM 6th edition), ${ }^{15}$ histological/cytological confirmed NSCLC, no prior thoracic radiation and a work-up according to national guidelines, ${ }^{16}$ including a staging FDG-PET-CT scan and a Magnetic Resonance Imaging (MRI) or a contrast-enhanced CT scan of the brain. A World Health Organisation Performance Status (WHO-PS) of 0-2 was required and a weight loss of less than $10 \%$ in 6 months. All patients had to have a moderate to good lung function $\mathrm{FEV}_{1}$ (Forced Expiratory Volume in the first second) $\geqslant 30 \%$ and DLCO (Carbon Monoxide Diffuse Capacity) $\geqslant 30 \%$ of predicted value.

\subsection{Study design and procedures}

Chemotherapy consisted of 1-2 cycles of carboplatin-gemcitabine (carboplatin AUC 5, gemcitabine $1250 \mathrm{mg} / \mathrm{m}^{2}$ ), followed by concurrent cisplatin-vinorelbine (cisplatin $40-50 \mathrm{mg} / \mathrm{m}^{2}$, vinorelbine $15-20 \mathrm{mg} / \mathrm{m}^{2}$ ) or concurrent cisplatin-etoposide every 3 weeks (cisplatin $75-80 \mathrm{mg} / \mathrm{m}^{2}$ day 1 , etoposide $100 \mathrm{mg} / \mathrm{m}^{2}$ day 1-3) with radiotherapy. The regimen depended on the referring hospital. Dose-reduction was applied according to guidelines and in case of renal failure cisplatin 
was substituted by carboplatin. Radiation treatment planning was performed during the first cycle of chemotherapy and radiotherapy was intended to start at the first day of the second cycle of chemotherapy. The study was approved by the institutional review board and registered on clinicaltrials.gov (NCT00572325). Informed consent was obtained from all patients prior to radiotherapy.

\subsubsection{Radiotherapy treatment planning}

A PET-CT scan and a 4D-CT scan was performed before start of radiation (Biograph, Siemens) and delineation was based on fused PET-CT images. ${ }^{9,11}$ The total gross tumour volume (GTV) consisted of the primary tumour (GTV-1; CT based volume based on the midventilation scan) and GTV-2. ${ }^{9}$ Only the initial PET-positive lymph nodal areas, based on the diagnostic PET-CT before any treatment, and nodes proven to be malignant were included in GTV-2. No elective mediastinal irradiation was carried out, according to European Organisation for Research and Treatment of Cancer (EORTC) guidelines. ${ }^{9}$ For the Clinical Target Volume (CTV-1 and CTV-2) a margin of $5 \mathrm{~mm}$ around GTV was used. The Planning Target Volume (PTV) was created by adding a $10 \mathrm{~mm}$ margin to CTV-1 and a $5 \mathrm{~mm}$ margin to CTV-2. For the calculation of the mean lung dose (MLD), the volume of both lungs minus GTV was considered. ${ }^{9}$ The spinal cord was drawn at the inner margin of the bony spinal canal.

A $3 \mathrm{D}$ conformal treatment plan was calculated $(\mathrm{XiO}$, CMS, Inc.) according to the International Commission on Radiation Units and Measurements (ICRU) Report $50^{17}$ using a Fast Fourier Transform convolution-superposition algorithm taking into account inhomogeneity corrections. Patients were irradiated with a linear accelerator (Siemens Oncor, Siemens Medical Solutions, Concord, CA). All patients were treated with $6 \mathrm{MV}$ or $10 \mathrm{MV}$ photon beams. ${ }^{9,18}$ Treatment verification was performed using EPID measurements.

\subsubsection{Treatment description}

For all patients enrolled, the prescribed dose was individually escalated until a dose-limiting normal tissue constraint was reached: a maximal MLD of $19.0 \pm 1.0 \mathrm{~Gy}$, a maximal spinal cord dose of $54.0 \pm 0.5 \mathrm{~Gy}$, and a maximal plexus brachialis dose of 66 Gy was applied. ${ }^{19-22}$ Since most tumours were centrally located and/or had involved mediastinal nodes the maximal allowed dose was 69 Gy to respect a dose inhomogeneity with a maximum of $107 \%$ to great vessels or main bronchi of $74 \mathrm{~Gy} .{ }^{22,23}$ No specific oesophageal dose constraint was used, except a Dmax of 74 Gy. ${ }^{24}$ The dose was delivered in an accelerated scheme: 1.5 Gy fractions twice daily up to $45 \mathrm{~Gy}$ with an interfraction interval of at least 8-hours, followed by once daily fractions of $2 \mathrm{~Gy}$ based on the ESPATÜ phase III trial scheme. ${ }^{13}$ The biological equivalent dose for tumour in 2 Gy fractions was calculated using the linear quadratic model ${ }^{25-27}$ and corrected for overall treatment time $\left(\mathrm{EQD}_{2, \mathrm{~T}}\right) .{ }^{10}$

\subsection{End-points}

Primary end-point was OS, secondary end-point progression free survival (PFS) and toxicity. Patients were seen before start of radiotherapy, weekly during treatment, 1 month after radiotherapy and every 3-6 months for the first 2 years and yearly afterwards. Additional toxicity information was collected by validated questionnaires from 2009 on. Acute ( $<90$ days from start of radiotherapy) and late ( $\geqslant 90$ days from start of radiotherapy) toxicity was scored according to Common Terminology Criteria for Adverse Events v3.0 (CTCAE). Clinical tests (imaging) were used to determine local progression or distant failure. If progression was suspected a (PET-) CT was performed and if necessary a biopsy was considered. Survival status was evaluated in February 2011 using the GBA system, a decentralised population registration system containing information about all inhabitants of The Netherlands.

\section{Statistical analysis}

Assuming an increase in 2-year OS of $10 \%$ compared to a classical concurrent chemo-radiation schedule to be successful, a number of 145 patients was calculated to provide sufficient statistical power (power $=0.8$, alpha $=0.05, \mathrm{p} 0=35 \%, \mathrm{p} 1=45 \%$ ). Due to the clinical implementation of Intensity-Modulated Radiation Therapy (IMRT) the inclusion of patients was closed at 137 patients, since IMRT results in other dose distributions than 3DCRT. The SPSS software (SPSS for Windows, Chicago, IL) was used for statistical analysis. OS was defined as time from diagnosis till death using the Kaplan-Meier method (log-rank test for comparison of survival). PFS was defined as the time from diagnosis until first clinical event (local or distant progression or death from any cause). Median survival rates are expressed with their 95\% confidence intervals (CI). The Cox proportional hazards model was used for multivariate analysis testing the following variables: primary tumour, nodal and total gross tumour volume (GTV-1, GTV-2, total GTV), EQD2,T, Total tumour (TTD), stage, WHO-PS, gender, age, histology and type of chemotherapy. Crude incidences of pulmonary complaints (cough and dyspnoea), oesophageal dysphagia were calculated.

\section{Findings}

\subsection{Patient and treatment characteristics}

Between 1st April 2006 and 31st December 2009137 patients, 88 males and 49 females with a median age of 
Table 1

Patient, tumor and treatment characteristics.

\begin{tabular}{|c|c|c|}
\hline Characteristic & $\begin{array}{l}\text { No. of } \\
\text { patients }\end{array}$ & $(\%)$ \\
\hline Age (median in years and range) & 63.2 & $(40-80)$ \\
\hline $\begin{array}{l}\text { Sex } \\
\quad \text { Male } \\
\text { Female }\end{array}$ & $\begin{array}{l}88 \\
49\end{array}$ & $\begin{array}{l}(64.2) \\
(35.8)\end{array}$ \\
\hline $\begin{array}{l}\text { WHO-PS } \\
0 \\
1 \\
2 \\
3\end{array}$ & $\begin{array}{r}68 \\
58 \\
10 \\
1\end{array}$ & $\begin{array}{l}(49.6) \\
(42.3) \\
(7.3) \\
(0.7)\end{array}$ \\
\hline $\begin{array}{l}\text { Histology } \\
\text { Squamous cell carcinoma } \\
\text { Adenocarcinoma } \\
\text { Large cell/undifferentiated } \\
\text { Unknown }\end{array}$ & $\begin{array}{r}40 \\
22 \\
73 \\
2\end{array}$ & $\begin{array}{l}(29.2) \\
(16.1) \\
(53.2) \\
(1.5)\end{array}$ \\
\hline $\begin{array}{l}\text { Clinical stage } \\
\text { IIB } \\
\text { IIIA } \\
\text { IIIB }\end{array}$ & $\begin{array}{r}1 \\
50 \\
86\end{array}$ & $\begin{array}{l}(0.7) \\
(36.5) \\
(62.8)\end{array}$ \\
\hline $\begin{array}{l}\text { Type of concurrent chemotherapy } \\
\text { Cisplatin-etoposide } \\
\text { Cisplatin-vinorelbine } \\
\text { Carboplatin based }\end{array}$ & $\begin{array}{r}94 \\
39 \\
4\end{array}$ & $\begin{array}{l}(68.6) \\
(28.5) \\
(2.9)\end{array}$ \\
\hline $\begin{array}{l}\text { Gross tumour volume } \\
\text { Median (range) total tumour load } \\
\text { in cc }\end{array}$ & 76.4 & $(3.7-518.9)$ \\
\hline $\begin{array}{l}\text { Prescribed TTD } \\
\text { Median (range) in Gy }\end{array}$ & 65.0 & $(51-69)$ \\
\hline $\begin{array}{l}\mathrm{EQD}_{2, \mathrm{~T}} \text { corrected for proliferation } \\
\text { Median (range) in Gy }\end{array}$ & 53.9 & $(43.1-63.1)$ \\
\hline $\begin{array}{l}\text { MLD } \\
\quad \text { Median (range) in Gy }\end{array}$ & 16.3 & $(4.4-21.0)$ \\
\hline $\begin{array}{l}\text { OTT } \\
\text { Median (range) in days }\end{array}$ & 35 & $(18-48)$ \\
\hline
\end{tabular}

GTV $=$ total gross tumour volume, TTD $=$ total tumour dose, $\mathrm{EQD}_{2, \mathrm{~T}}=$ equivalent dose in $2 \mathrm{~Gy}$ fractions corrected for proliferation, $\mathrm{MLD}=$ mean lung dose, OTT $=$ overall treatment time and WHO-PS $=$ World Health Organisation Performance Score.

$63.2 \pm 9.0$ years (range: $40-80$ years) were enrolled. Patient and tumour characteristics are presented in Table 1. Stage distribution was as following: IIB $0.7 \%(n=1)$, IIIA $36.5 \%(n=50)$, IIIB $62.8 \%(n=86)$, including 8 patients $(5.8 \%)$ with recurrent (stage III) disease. Stage IIIB $(n=86)$ consisted of 42 patients with T4N0-2 disease, 36 patients with T0-3N3 disease and 8 patients with T4N3 disease. Concurrent chemotherapy consisted in 94 patients $(68.6 \%)$ of cisplatin-etoposide, in 39 patients $(28.5 \%)$ of cisplatin-vinorelbine and in 4 patients carboplatin based $(2.9 \%)$. The median interval between the 1 st cycle of chemotherapy and start of radiotherapy was $22 \pm 15.0$ days ( $0-85$ days). The median total GTV was $76.4 \pm 94.1 \mathrm{cc}$ $(3.7-518.9 \mathrm{cc})$. Only 22 patients $(16.1 \%)$ had N0 disease, while $3(2.7 \%), 68(49.6 \%)$ and 44 patients $(32.1 \%)$ had
$\mathrm{N} 1, \mathrm{~N} 2$ or N3 disease respectively. The median dose for the total group of patients was $65.0 \pm 6.0 \mathrm{~Gy}(51-69 \mathrm{~Gy})$ delivered in a median OTT of $35 \pm 5.7$ days (18-48 days). This equals a median $\mathrm{EQD}_{2, \mathrm{~T}}$ of $53.9 \pm 3.9 \mathrm{~Gy}$ (range 43.1-63.1 Gy), which equals a dose of 72 Gy delivered in 36 once-daily fractions of $2 \mathrm{~Gy}$. Five patients did not complete their radiation: 2 patients due to intercurrent disease (cerebrovascular accident, myocardial infarction) and 3 patients wished to stop since the schedule was too exhausting. The median MLD was $16.3 \pm 3.5 \mathrm{~Gy}$ (range 4.4 $21.0 \mathrm{~Gy})$ and the dose to the spinal cord $49.2 \pm 10.2 \mathrm{~Gy}$ (range 14.1-56.9 Gy). In 43 patients $(31.4 \%)$ the MLD was dose-limiting. In 10 patients $(7.3 \%)$ a protocol violation was encountered; 1 patient with stage IIB with a large tumour $(315.1 \mathrm{cc})$ was included, and in 9 patients $(6.6 \%)$ the dose constraints were not fulfilled: $2.2 \%$ an MLD $>20$ Gy (resp. 20.2, 20.4 and 21.0 Gy) and 4.4\% a maximal dose to the spinal cord $>54.5$ Gy (resp. 54.8, $55.0,55.3,56.4,56.4$ and $56.9 \mathrm{~Gy}$ ).

\subsection{Survival}

The median follow-up time was 30.9 months $(95 \% \mathrm{CI}$ 28.5-33.5 months). At the time of analysis 76 patients $(55.5 \%)$ had died. The median OS was 25.0 months (95\%CI 19.8-30.3 months) with a 1-year OS of $72.2 \%$ and a 2-year OS of $52.4 \%$ (Fig. 1a). For the different stages the median OS was as following: stage IIIA 24.2 months (95\%CI $15.5-32.9$ months) and stage IIIB 29.1 months $(95 \%$ CI $18.1-40.1$ months; $p=0.51$; Fig. 1b). The median PFS was 14.0 months $(95 \% \mathrm{CI}$ 9.5-18.5 months) with a 1-year PFS of $54.7 \%$ and a 2year PFS of $35.5 \%$ (Fig. 1c). Eighty patients (58.4\%) showed recurrent disease: $5.1 \%(n=7)$ an isolated local recurrence, $4.4 \%(n=6)$ an isolated regional recurrence, $5.1 \%(n=7)$ a combined local and regional recurrence and $27.0 \%(n=37)$ distant metastases only. Out of these 37 patients, $21(56.8 \%)$ had cerebral metastases as first site of progression. In another $16.8 \%(n=23)$ local-regional progression was simultaneously (within 1 month) detected with distant metastases.

\subsection{Uni-and multi-variate analysis survival}

On univariate analysis, OS was better with a WHO-PS of $0 \quad(p=0.009)$, smaller nodal volume (GTV-2; $p=0.015)$ and a higher $\mathrm{EQD}_{2, \mathrm{~T}}(p=0.037)$. All other factors were not correlated with OS (Table 2). On multivariate analysis a favourable WHO-PS $(p=0.006)$, smaller nodal volume (GTV-2; $p=0.022)$ and a higher $\mathrm{EQD}_{2, \mathrm{~T}}$ $(p=0.044)$ remained independent factors for a better OS.

\subsection{Toxicity}

Toxicity is depicted in Fig. 2. Severe acute toxicity ( $\geqslant \mathrm{G} 3, n=49,35.8 \%$ ) consisted mainly of G3 dysphagia. 

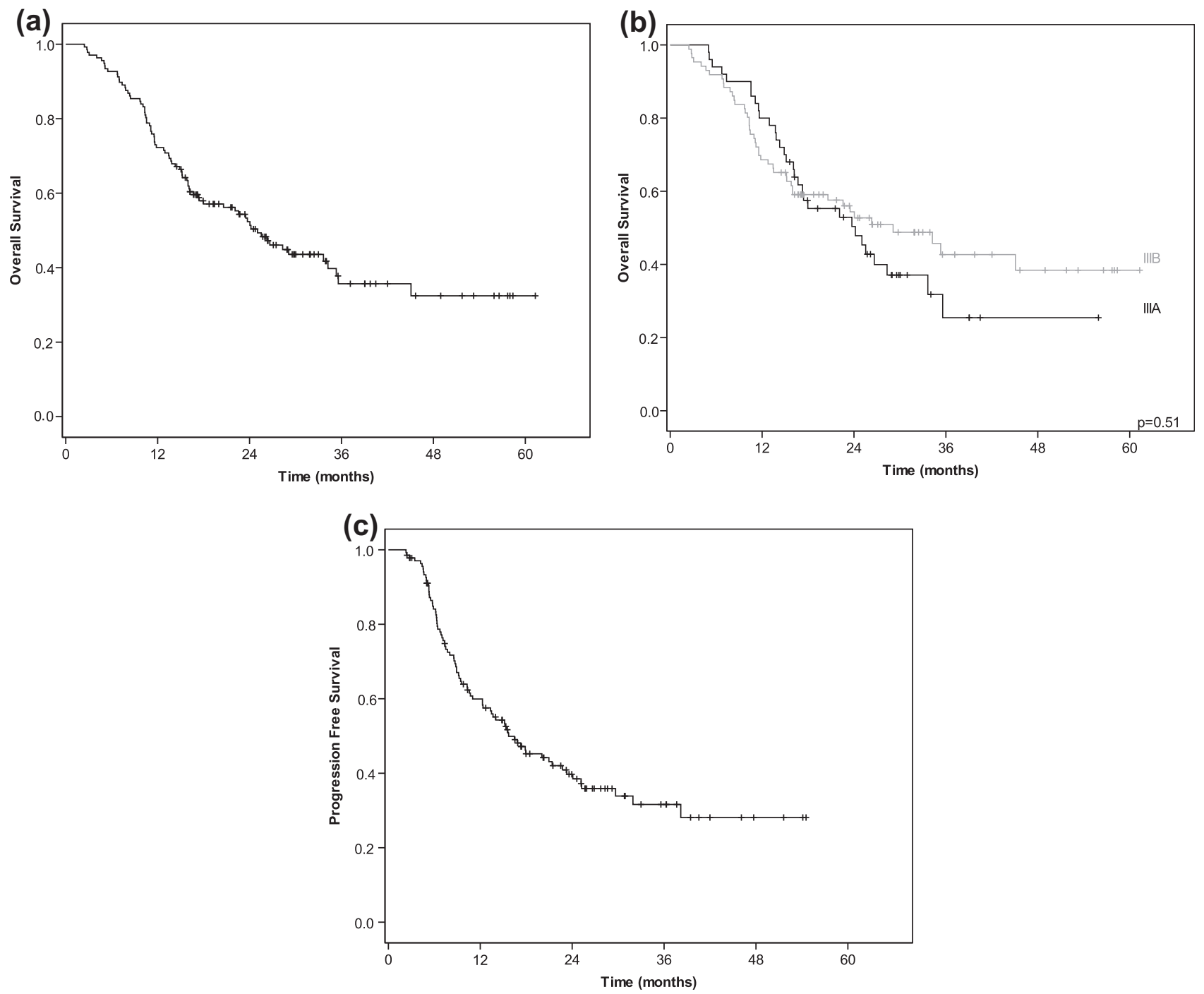

Fig. 1. Actuarial Overall Survival (OS) for total group of patients (a), for stages IIIA and IIIB (b), and the actuarial Progression Free Survival (PFS) (c) in months for the total group of patients.

Most patients developed no $(8.8 \%)$ or mild dysphagia (G1:28.5\%, G2:37.2\%), while G3 dysphagia during radiotherapy was observed in $25.5 \%(n=35)$. Severe pulmonary complaints were less frequent: G3 and G4 dyspnoea were observed in $2.9 \%$ and $0.7 \%$ respectively and G3 cough in $8.0 \%$ of patients. One month after radiotherapy G3 dysphagia was observed in only 9 patients $(6.6 \%)$.

In total 6 patients $(4.4 \%)$ died within 3 months after end of radiotherapy; two due to not otherwise defined pulmonary causes, 1 patient sepsis, 1 patient cardiomyopathy, 1 patient of an abdominal aorta aneurysm and 1 patient of an unknown cause at home.

For severe late toxicity ( $\geqslant \mathrm{G} 3 ; \geqslant 90$ days post-radiotherapy) 131 patients were available. In 10 patients $(7.3 \%) \geqslant \mathrm{G} 3$ toxicity was observed: in 6 patients $(4.6 \%)$ this was a G3 dysphagia (in 5 patients due to a stricture or stenosis and in 1 patient an oesophageal ulcer). With regard to severe pulmonary toxicity a thoracic empyema or fistula was diagnosed in 2 patients $(1.5 \%) 14$ and 6 months after radiotherapy respectively. One patient had a pneumothorax 3 months after radiotherapy and developed an empyema subsequently. Three patients $(2.3 \%)$ had grade 3 dyspnoea and 1 patient $(0.8 \%)$ died of a radiation pneumonitis (grade 5) 3.5 months after radiotherapy. This patient was an $80-$ year old male (WHO-PS 1, FEV $176 \%$, DLCO 77\%), who received a dose of 65 Gy with a MLD of $19.5 \mathrm{~Gy}$. No case of myelitis was observed.

\section{Discussion}

Although improvements in treatment of NSCLC have occurred, the prognosis of locally advanced NSCLC remains poor. The importance of both total radiation $\operatorname{dose}^{26}$ and overall treatment time ${ }^{7}$ have been demonstrated for local tumour control and survival. $^{2,7,14}$ Therefore many groups have tried to increase 
Table 2

Univariate and multivariate analysis for overall survival (OS).

\begin{tabular}{|c|c|c|}
\hline & \multicolumn{2}{|c|}{ Overall survival } \\
\hline & Univariate & Multivariate \\
\hline WHO-PS 0 versus WHO-PS $\geqslant 1$ & 0.009 & 0.006 \\
\hline $\begin{array}{l}\text { GTV- } 2<\text { median versus GTV- } 2 \geqslant \\
\text { median }\end{array}$ & 0.015 & 0.022 \\
\hline $\begin{array}{l}\mathrm{EQD}_{2, \mathrm{~T}} \geqslant \text { median versus } \mathrm{EQD}_{2, \mathrm{~T}}< \\
\text { median }\end{array}$ & 0.037 & 0.044 \\
\hline TTD $\geqslant$ median versus TTD $<$ median & 0.20 & NA \\
\hline $\begin{array}{l}\text { Total GTV } \geqslant \text { median versus total GTV }< \\
\text { median }\end{array}$ & 0.22 & NA \\
\hline Histology & 0.44 & NA \\
\hline Stage IIIA versus IIIB & 0.51 & NA \\
\hline Type of chemotherapy & 0.71 & NA \\
\hline $\begin{array}{l}\text { GTV }-1 \geqslant \text { median versus GTV }-1< \\
\text { median }\end{array}$ & 0.82 & NA \\
\hline Gender & 0.83 & NA \\
\hline Age $\geqslant$ median versus age $<$ median & 0.85 & NA \\
\hline
\end{tabular}

$\mathrm{GTV}=$ total gross tumour volume, $\mathrm{TTD}=$ total tumour, $\mathrm{EQD}_{2, \mathrm{~T}}=$ equivalent dose in $2 \mathrm{~Gy}$ fractions corrected for proliferation, and WHO-PS $=$ world health organisation performance score, $\mathrm{NA}=$ not analysed.
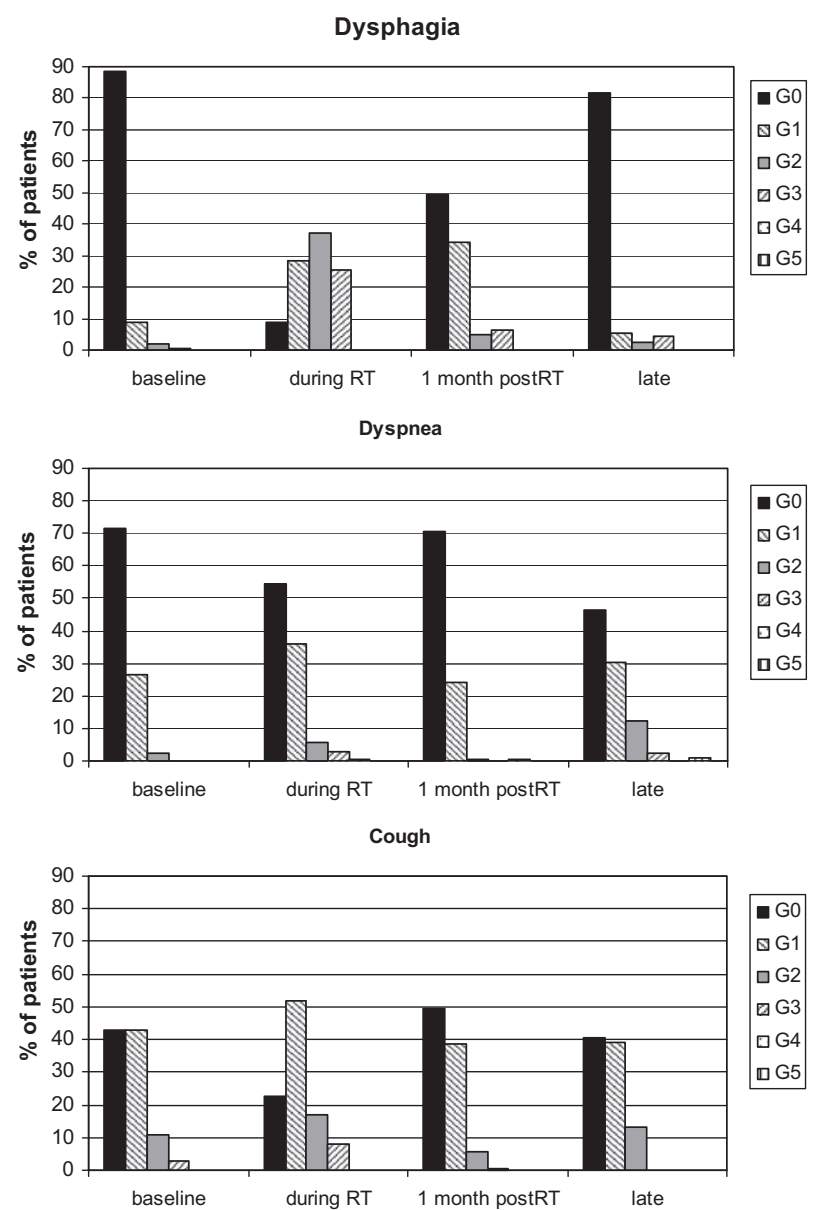

Fig. 2. Percentage of patients with toxicity: maximal scoring according to Common Terminology Criteria for Adverse Events v3.0 (CTCAEcriteria v3.0) for baseline, acute toxicity during radiotherapy, 1 month after radiotherapy and late toxicity ( $>90$ days) for cough (a), dyspnoea (b) and oesophagitis (c). the dose and/or reduce the overall treatment time by applying accelerated radiotherapy. ${ }^{6,12,28,29}$

Another strategy to improve outcome in stage III NSCLC is concurrent chemo-radiation. A recent metaanalysis has shown the superiority of concomitant chemo-radiation over sequential chemo-radiation, 2year survival of $35 \%$ and $30 \%$ respectively. ${ }^{2}$ In the recent prospective phase II RTOG-0324 trial in which 93 patients were treated with concurrent carboplatin-paclitaxel-cetuximab and radiotherapy to a dose of $63 \mathrm{~Gy}$ in 35 once-daily fractions, the median survival was 22.7 months and the 2-year overall survival $49.3 \%{ }^{8}$

These results were stated to be better than any previously reported RTOG study and promising enough to be the basis of a randomised phase III trial. Without the addition of cetuximab, our results of a median overall survival of 25.0 months and a 2-year overall survival rate of $52.4 \%$ in a 137 -patients prospective study are in line with the best results that were achieved in RTOG-0324.

Although the present trial is a phase II non-randomised mono-centre trial the selection criteria were not very stringent: no age criteria were applied $(25 \%$ of patients $>70$ years, $10.2 \%>75$ years), patients with N3 disease (32.1\%), including supraclavicular node involvement and the median tumour volume was rather large $(76 \mathrm{cc}$ ). In two phase I trials (RTOG 0117 and CCTG 0028) and in the randomised phase II CALGB 30105 trial the maximal tolerable dose was 74 Gy in 37 fractions in 7.4 weeks, which is biologically similar to our schedule. However, due to the dose constraints together with a fixed tumour dose, it is likely that the patients included in these studies had smaller tumours. Unfortunately no data on tumour volumes are available in the latter studies, although the percentage of IIIB disease was lower $(11 \%, 23 \%$ and $50 \%$ respectively) compared to ours $(63 \%)$. This might be caused by exclusion of $\mathrm{N} 3$ disease in supraclavicular nodes in some studies. Only $25 \%$ of patients included in our study would have been able to receive a physical dose of $74 \mathrm{~Gy}$, due to MLD or spinal cord constraints.

This series includes a rather large number of large cell carcinoma $(53.2 \%)$, due to the historical tendency in some of the referring hospitals to specify a tumour as a large cell carcinoma if the histology was not typical adenocarcinoma or squamous cell carcinoma.

Since all patients included were treated from 2006, staging included a PET-CT scan and brain imaging. This might lead to some stage migration and therefore selection compared to some other studies. Nevertheless, our results are comparable with these of the aforementioned trials, even though a lower physical radiation dose was delivered, be it in a shorter overall treatment time, thus indirectly supporting the biological activity of the present schedule.

We observed a 2-year PFS of $39.7 \%$ and a 2-year OS of $52.4 \%$, which is equal to or even better than observed 
by other authors. ${ }^{2,3,5,8}$ Results were even comparable to the results of 28 patients included in the ESPATÜ study with potentially resectable locally advanced NSCLC, who received accelerated chemo-radiation and no resection, showing a 2-year OS of $50 \% .{ }^{13}$ The meta-analysis showed a 2-year PFS for concurrent chemo-radiation of $22.7 \%$. The first event was mainly distant metastasis $(26.7 \%)$ and less frequently loco-regional recurrence $(14.6 \%)$ or a combination of both $(16.8 \%)$ in the present series, compared to $34 \%$ distant metastasis and $27 \%$ loco-regional recurrence in the meta-analysis, respectively. ${ }^{2}$ Although the frequency of distant metastasis remains high, to the best of our knowledge, further treatment intensification by adding induction chemotherapy or consolidation chemotherapy or targeted agents to concurrent chemo-radiation has not demonstrated any survival benefit compared to concurrent chemo-radiation alone..$^{30,31}$

Dose prescription was based on normal tissue constraints, like MLD. Although no single parameter can predict lung toxicity, the MLD together with the V20 are the most robust parameters predictive for lung toxicity. ${ }^{9}$ The median radiation dose in this study was $65 \mathrm{~Gy}$, and $27 \%$ of patients could receive the maximal allowed dose (69 Gy). By applying IMRT this number could probably be increased. ${ }^{32,33}$ However, it is not totally clear whether applying IMRT techniques will lead to similar regional control rates, since the incidental dose to mediastinal lymph nodes is higher using 3D conformal techniques than IMRT. Future studies evaluating IMRT should answer this question, as well if the balance of dose-escalation by IMRT and reducing dose to elective nodes and organs at risk will lead to better control rates and similar or lower toxicity, like pneumonitis.

The rate of oesophageal toxicity was rather high although it consisted mainly of (transient) oesophageal toxicity (acute G3 dysphagia: 24\%). This rate is somewhat higher than mentioned in literature $(<20 \%)$ and might be caused by the fact that no specific oesophageal dose constraints were applied and the accelerated radiation scheme. ${ }^{5}$ In $4 \%$ of patients severe late oesophageal toxicity was observed, which is in line with literature. ${ }^{3,5}$ With regard to late pulmonary toxicity we focused on $\geqslant$ grade $3(3 \%)$, since symptoms of pneumonitis, like dyspnoea and cough might be non-specific and intercurrent infections or exacerbation of COPD might confound scoring. We observed one lethal radiation pneumonitis $(0.8 \%)$. This compares well with literature. ${ }^{2,3,8}$

In conclusion, INDAR in concurrent chemo-radiation based on normal tissue constraints is feasible. The maximal dose of $69 \mathrm{~Gy}$ is physically lower than prescribed in other dose-escalation schemes, but biologically equivalent due to the short overall treatment time, and is even feasible in patients with large tumour volumes and multi-level N2-3 disease. It has both acceptable transient acute toxicity as well as limited severe late toxicity and shows promising results with a 2 year OS of $52.4 \%$. One of the challenges in the future is to further individualise treatment of stage III NSCLC, not only with regard to radiation dose, but also to tailor systemic therapy to the individual patient to find a balance between effect and toxicity.

\section{Conflict of interest statement}

None declared.

\section{References}

1. Jemal A, Bray F, Center MM, Ferlay J, Ward E, Forman D. Global cancer statistics. CA Cancer J Clin 2011 Mar-Apr;61(2):69-90.

2. Auperin A, Le Pechoux C, Rolland E, et al. Meta-analysis of concomitant versus sequential radiochemotherapy in locally advanced non-small-cell lung cancer. J Clin Oncol 2010 May 1;28(13):2181-90.

3. Bradley JD, Bae K, Graham MV, et al. Primary analysis of the phase II component of a phase I/II dose intensification study using three-dimensional conformal radiation therapy and concurrent chemotherapy for patients with inoperable non-small-cell lung cancer: RTOG 0117. J Clin Oncol 2010 May 10;28(14):2475-80.

4. Chang AJ, Bradley JD. Clinical perspectives on dose escalation for non-small-cell lung cancer. Clin Lung Cancer 2010 Sep 1;11(5):299-302.

5. Curran Jr WJ, Paulus R, Langer CJ, et al. Sequential vs concurrent chemoradiation for stage III non-small cell lung cancer: randomized phase III trial RTOG 9410. J Natl Cancer Inst 2011 Oct 5;103(19):1452-60.

6. Wurstbauer K, Weise H, Deutschmann H, et al. Non-small cell lung cancer in stages I-IIIB: long-term results of definitive radiotherapy with doses $>/=80 \mathrm{~Gy}$ in standard fractionation. Strahlenther Onkol 2010 Oct;186(10):551-7.

7. Saunders M, Dische S, Barrett A, Harvey A, Griffiths G, Palmar M. Continuous, hyperfractionated, accelerated radiotherapy (CHART) versus conventional radiotherapy in non-small cell lung cancer: mature data from the randomised multicentre trial. CHART Steering committee. Radiother Oncol 1999 Aug;52(2):137-48.

8. Blumenschein Jr GR, Paulus R, Curran WJ, et al. Phase II study of cetuximab in combination with chemoradiation in patients with stage IIIA/B non-small-cell lung cancer: RTOG 0324. J Clin Oncol 2011 Jun 10;29(17):2312-8.

9. De Ruysscher D, Faivre-Finn C, Nestle U, et al. European Organisation for Research and Treatment of Cancer recommendations for planning and delivery of high-dose, high-precision radiotherapy for lung cancer. J Clin Oncol 2010 Dec 20;28(36):5301-10.

10. van Baardwijk A, Bosmans G, Bentzen SM, et al. Radiation dose prescription for non-small-cell lung cancer according to normal tissue dose constraints: an in silico clinical trial. Int J Radiat Oncol Biol Phys 2008 Jul 15;71(4):1103-10.

11. van Baardwijk A, Bosmans G, Boersma L, et al. Individualized radical radiotherapy of non-small-cell lung cancer based on normal tissue dose constraints: a feasibility study. Int $J$ Radiat Oncol Biol Phys 2008 Aug 1;71(5):1394-401.

12. van Baardwijk A, Wanders S, Boersma L, et al. Mature results of an individualized radiation dose prescription study based on normal tissue constraints in stages I to III non-small-cell lung cancer. J Clin Oncol 2010 Mar 10;28(8):1380-6.

13. Pottgen C, Eberhardt WE, Gauler T, et al. Intensified high-dose chemoradiotherapy with induction chemotherapy in patients with locally advanced non-small-cell lung cancer-safety and toxicity 
results within a prospective trial. Int J Radiat Oncol Biol Phys 2010 Mar 1;76(3):809-15.

14. Machtay M, Bae K, Movsas B, et al. Higher biologically effective dose of radiotherapy is associated with improved outcomes for locally advanced non-small cell lung carcinoma treated with chemoradiation: an analysis of the radiation therapy oncology group. Int $\mathbf{J}$ Radiat Oncol Biol Phys 2010 Oct 25, Epub ahead of print.

15. Sobin LH, Wittekind $\mathrm{C}$, editors. International union against cancer (UICC). TNM classification of malignant tumours. 6th ed. New York: Wiley-Liss; 2002.

16. Landelijke Werkgroep Longtumoren. Niet-kleincellig longcarcinoom, landelijke richtlijn (version 1.3). <www.oncoline.nl >; 2004.

17. ICRU. International Commission on Radiation Units and Measurements Report 50: Prescribing, recording, and reporting photon beam therapy; 1993.

18. Elmpt W, Ollers M, Velders M, et al. Transition from a simple to a more advanced dose calculation algorithm for radiotherapy of non-small cell lung cancer (NSCLC): implications for clinical implementation in an individualized dose-escalation protocol. Radiother Oncol 2008 Sep;88(3):326-34.

19. Schultheiss TE, Kun LE, Ang KK, Stephens LC. Radiation response of the central nervous system. Int J Radiat Oncol Biol Phys 1995 Mar 30;31(5):1093-112.

20. Kelsey CR, Kahn D, Hollis DR, et al. Radiation-induced narrowing of the tracheobronchial tree: an in-depth analysis. Lung Cancer 2006 Apr;52(1):111-6.

21. Maguire PD, Marks LB, Sibley GS, et al. 73.6 Gy and beyond: hyperfractionated, accelerated radiotherapy for non-small-cell lung cancer. J Clin Oncol 2001 Feb 1;19(3):705-11.

22. Marks LB, Bentzen SM, Deasy JO, et al. Radiation dose-volume effects in the lung. Int J Radiat Oncol Biol Phys 2010 Mar 1;76(3 ):S70-6.

23. Marks LB, Garst J, Socinski MA, et al. Carboplatin/paclitaxel or carboplatin/vinorelbine followed by accelerated hyperfractionated conformal radiation therapy: report of a prospective phase I dose escalation trial from the Carolina Conformal Therapy Consortium. J Clin Oncol 2004 Nov 1;22(21):4329-40.

24. Werner-Wasik M, Yorke E, Deasy J, Nam J, Marks LB. Radiation dose-volume effects in the esophagus. Int $J$ Radiat Oncol Biol Phys 2010 Mar 1;76(3 Suppl):S86-93.
25. Bentzen SM, Saunders MI, Dische S. From CHART to CHARTWEL in non-small cell lung cancer: clinical radiobiological modelling of the expected change in outcome. Clin Oncol ( $R$ Coll Radiol) 2002 Oct;14(5):372-81.

26. Fowler JF, Tome WA, Fenwick JD, Mehta MP. A challenge to traditional radiation oncology. Int J Radiat Oncol Biol Phys 2004 Nov 15;60(4):1241-56.

27. Steel G. Basic Clinical Radiobiology. 3rd ed. London: Hodder Arnold Publications; 2002.

28. Jenkins P, Anderson S, Wronski S, Ashton A. A phase II trial of induction chemotherapy followed by continuous hyperfractionated accelerated radiotherapy in locally advanced non-small-cell lung cancer. Radiother Oncol 2009 May 10.

29. Senan S, Cardenal F, Vansteenkiste J, et al. A randomized phase II study comparing induction or consolidation chemotherapy with cisplatin-docetaxel, plus radical concurrent chemoradiotherapy with cisplatin-docetaxel, in patients with unresectable locally advanced non-small-cell lung cancer. Ann Oncol 2011 Mar;22(3):553-8.

30. Kelly K, Chansky K, Gaspar LE, et al. Phase III trial of maintenance gefitinib or placebo after concurrent chemoradiotherapy and docetaxel consolidation in inoperable stage III nonsmall-cell lung cancer: SWOG S0023. J Clin Oncol 2008 May 20;26(15):2450-6.

31. Hanna N, Neubauer M, Yiannoutsos C, et al. Phase III study of cisplatin, etoposide, and concurrent chest radiation with or without consolidation docetaxel in patients with inoperable stage III non-small-cell lung cancer: the Hoosier Oncology Group and U.S. Oncology. J Clin Oncol 2008 Dec 10;26(35):5755-60.

32. Lievens $\mathrm{Y}$, Nulens A, Gaber MA, et al. Intensity-modulated radiotherapy for locally advanced non-small-cell lung cancer: a dose-escalation planning study. Int J Radiat Oncol Biol Phys. 2010 Sep 30, Epub ahead of print.

33. Grills IS, Yan D, Martinez AA, Vicini FA, Wong JW, Kestin LL. Potential for reduced toxicity and dose escalation in the treatment of inoperable non-small-cell lung cancer: a comparison of intensity-modulated radiation therapy (IMRT), 3D conformal radiation, and elective nodal irradiation. Int $J$ Radiat Oncol Biol Phys 2003 Nov 1;57(3):875-90. 